\title{
Endobronchial Granular Cell Tumor
}

\author{
Endobronşiyal Granüler Hücreli Tümör
}

Gülbanu Horzum Ekinci', Sinem Güngör', Ayşe Ersev², Esen Akkaya', Osman Hacıömeroğlu', Adnan Yılmaz'

\section{Abstract}

Pulmonary granular cell tumors are rare lesions, with approximately 100 reported cases in the literature. We present a case of pulmonary granular cell tumor. A 21 -year-old female was admitted to our hospital with a long history of chronic coughing. The computed tomography scan of the thorax showed an infiltrate in the anterior segment of the right lower lobe. The flexible bronchoscopy revealed infiltration at the entrance of the right lower lobe bronchus. The bronchoscopic biopsy revealed the diagnosis of granular cell tumor. She underwent a right lower lobectomy. Forty-two months after surgery, the patient remains disease-free and there has been no recurrence of the tumor.

Key words: Granular cell tumor, bronchus, bronchoscopy, surgery.

\section{Özet}

Pulmoner granüler hücreli tümörler, literatürde yayınlanmış yaklaşık 100 olgu ile nadir lezyonlardır. Bir pulmoner granüler hücreli tümör olgusunu sunuyoruz. Yirmi bir yaşında kadın hasta uzun süredir devam eden kronik öksürük yakınması ile hastanemize başvurdu. Bilgisayarlı toraks tomografisi sağ alt lobda infiltrasyon gösteriyordu. Fiberoptik bronkoskopide sağ alt lob girişinde infiltrasyon saptandı. Bronkoskopik biyopsi ile granüler hücreli tümör tanısı elde edildi. Hastaya sağ alt lobektomi yapıldı. Ameliyattan 42 ay sonra yapılan kontrolde rekürrens yoktu.

Anahtar Sözcükler: Granüler hücreli tümör, bronş, bronkoskopi, cerrahi.
Granular cell tumors (GCTs) are uncommon neoplasms that usually exhibit benign behavior (1). These tumors have been reported in various sites, but are more commonly found in the skin, subcutaneous tissue, tongue, oral mucosa, and breast (2). Occurrence in the lung is rare, and accounts for only $6 \%$ to $10 \%$ of all GCTs (3). GCTs of the lung can present as an endobronchial or parenchymal lesion $(1,4)$. Most endobronchial lesions are found in the trachea and central bronchi (5). We present a case of endobronchial granular cell tumor arising in the right lower lobe bronchus.
'Department of Chest Diseases, Süreyyapaşa Chest Diseases and Thoracic Surgery Training and Research Hospital, İstanbul, Turkey ${ }^{2}$ Department of Pathology, Süreyyapaşa Chest Diseases and Thoracic Surgery Training and Research Hospital, İstanbul, Turkey
'Süreyyapaşa Göğüs Hastalıkları ve Göğüs Cerrahisi Eğitim ve Araşııma Hastanesi, Göğüs Hastalıkları Kliniği, İstanbul ${ }^{2}$ Süreyyapaşa Göğüs Hastalıkları ve Göğüs Cerrahisi Eğitim ve Araşıırma Hastanesi, Patoloji Bölümü, İstanbul

Submitted (Başvuru tarihi): 23.1 1.2014 Accepted (Kabul tarihi): 07.01.2015

Correspondence (iletişim): Gülbanu Horzum Ekinci, Department of Chest Diseases, Süreyyapaşa Chest Diseases and Thoracic Surgery Training and Research Hospital, İstanbul, Turkey

e-mail: gulbanuh@hotmail.com 


\section{CASE}

A 21 -year-old Turkish woman was admitted to our hospital with a history of chronic cough for several months. She was a nonsmoker with history of asthma treated with salmeterol/fluticasone propionate combination and salbutamol. Her chest x-ray was normal. The physical examination was unremarkable. The routine laboratory tests were within normal limits. The computed tomography scan of the thorax showed an infiltrate in the anterior segment of the right lower lobe (Figure 1). Flexible bronchoscopy revealed mucosal infiltration at the entrance of the right lower lobe bronchus (Figure 2). Bronchoscopic biopsies indicated a granular cell tumor. Spirometry was within normal limits. She underwent a right lower lobectomy of the lung and lymph node dissection via right posterolateral thoracotomy through the 5 th intercostal space. Frozen examination showed that operation margins were normal and the patient was discharged from hospital after seven days without any further complications. Microscopic examination showed nests and sheets of plump, and round to polyhedral cells, underneath the bronchial epithelium. The cytoplasm of the tumor cells was eosinophilic, abundant and granular. The nuclei were centrally located small, and dark. No necrosis, pleomorphism or mitotic figures were seen. The overlying respiratory epithelium was hyperplastic and chronic inflammatory cells were seen throughout (Figure 3 and 4). All dissected lymph nodes were tumor-free. Immunohistochemical staining for S-100 protein was strongly positive in the tumor cells. The tumor cells did not stain for carcinoembryonic antigen, pancytokeratin, CD-68, and synaptophysin. The lesion was diagnosed as a GCT, based on the histological findings and results of an immunohistochemical panel. Forty-two months after surgery, the patient remained disease-free without any progression.

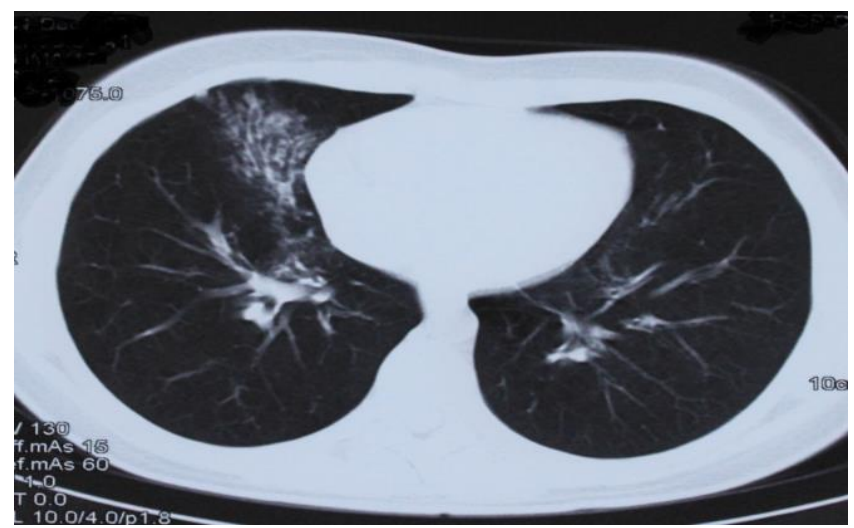

Figure 1: The computed tomography scan of the thorax shows an infiltrate in the anterior segment of the right lower lobe

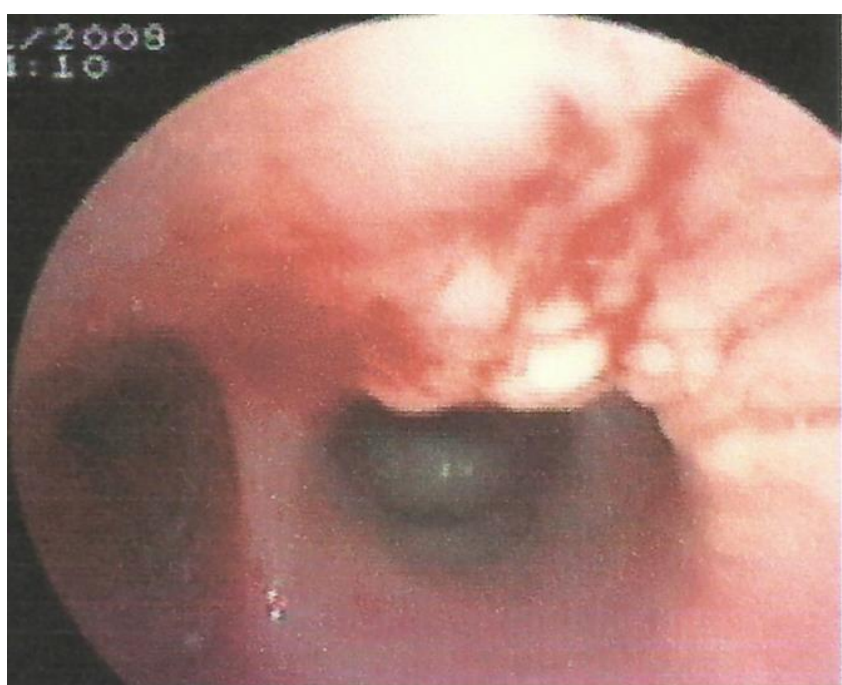

Figure 2: Flexible bronchoscopy shows mucosal infiltration at the entrance of the right lower lobe bronchus

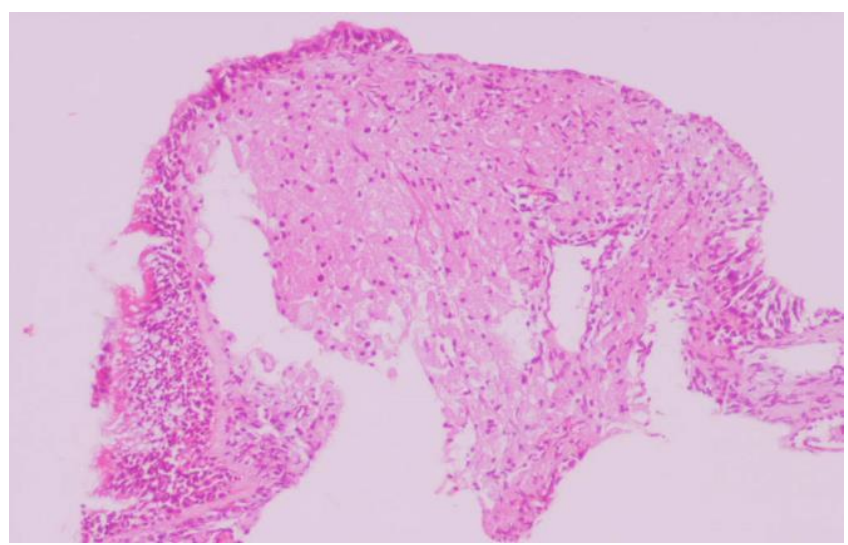

Figure 3: Tumor mass with indefinite borders underneath the bronchiolar epithelium (HE x 4)

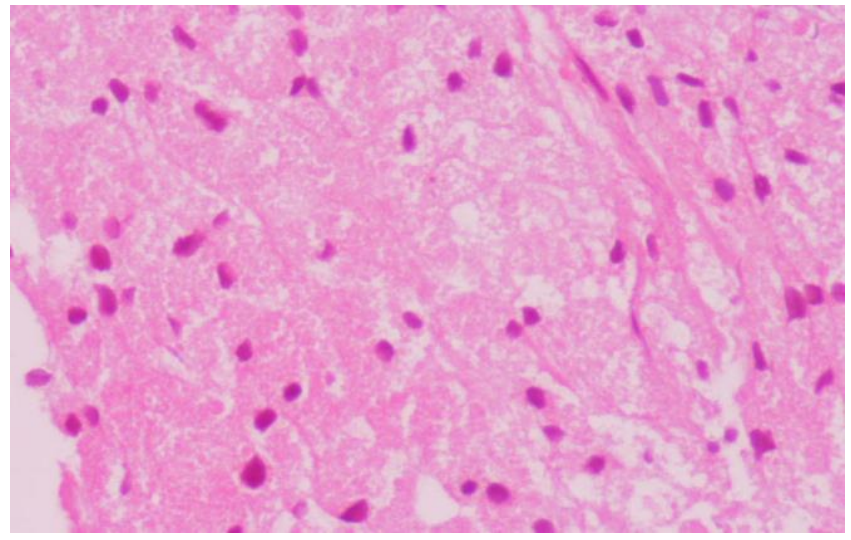

Figure 4: Round to polyhedral cells; eosinophilic granular cytoplasm, small dark nuclei (HE x 40)

\section{DISCUSSION}

GCT was first described by Abrikossoff in 1926. Since it was thought to arise from myoblasts, its earlier name was granular cell myoblastoma. Recent electron microscopic and immunohistochemical studies suggest a neurogenic 
origin from Schwann cells. Thus, the term 'granular cell tumor' was introduced $(1,3)$. GCTs can occur in almost any organ, but they are most frequent in the skin, subcutaneous tissue, tongue, oral mucosa, and breast (2). However, GCT of the lung is rare and accounts for only $6 \%$ to $10 \%$ of all GCTs $(1,3)$. Since the first case of GCT from the trachea and bronchus was reported in the late 1930s, approximately 100 cases of pulmonary GCT have been reported in the English literature $(1,6)$.

Pulmonary GCTs are generally endobronchial but sometimes they can be located peripherally. Approximately $90 \%$ of these tumors are endobronchial in location and they are usually found in the trachea and central bronchi, down to the segmental level, as in the present case $(1,3,5)$. Pulmonary GCTs are mostly seen in patients between 30 and 50 years old, but it can be diagnosed at any age $(1,7)$. Several reports indicated that there was no sex predilection in the incidence $(1,2,5,7)$. Approximately one-half of pulmonary GCT patients are asymptomatic at the presentation and the tumor is discovered as incidental radiologic, bronchoscopic, or operative findings $(1,7,8)$. Remaining patients may present with respiratory symptoms such as cough, dyspnea, hemoptysis, and stridor, and symptoms are related to the location and size of the tumor $(1,5,7,9)$. A chronic cough was only symptom in the present case. Chest $x$-ray may be normal, as was in our case. It may also present with pulmonary infiltrate, atelectasis, or visible tumors $(7,8)$. At the bronchoscopy the tumor has usually been described as a solitary endobronchial mass. However, it may also resemble an infiltrating carcinoma (8). Definitive diagnosis of these tumors is often provided by bronchoscopy because of the proximal airway location $(1,2,7)$. In our case, flexible bronchoscopic examination revealed infiltration in the right lower lobe, and pathologic diagnosis of the GCT was established by bronchoscopic biopsy.

Although GCTs generally exhibit benign behavior, malignant degeneration occurs in 1-3\% of all GCTs (5). Jiang et al. (10) reported a case of pulmonary malignant granular cell tumor. Up to $13 \%$ of pulmonary GCTs have been reported to coexist with other malignancies, most commonly with lung carcinoma $(3,6)$. It is known that pulmonary GCT has an infiltrative nature. These tumors may invade the full-thickness of the bronchial wall and infiltrate into the peribronchial tissue (7-9). Peribronchial tissue extension is present in $40 \%$ of pulmonary GCTs (7) Recurrent disease has been reported in patients with pulmonary GCTs after treatment $(1,7)$. Adequate treatment strategies for this tumor remain controversial (1). GCTs fail to respond to radiotherapy and chemotherapy (5). Current therapeutic options include endobronchial therapy and surgical resection $(1,2,5-9)$. It has been reported that bronchoscopic treatment of GCT may be attempted as the first approach for intraluminal tumors, with no recurrence (2). van der Maten et al. (9) suggested that endobronchial therapy was the primary treatment for endobronchial GCT. However, Hernandez et al. (8) reported that the incidence of recurrence was high after bronchoscopic treatment. It has been advocated that for tumors of less than $8 \mathrm{~mm}$ endobroscopic removal is more appropriate $(1,7,8)$. Tumors of $8-10 \mathrm{~mm}$ or larger are more likely to infiltrate through the bronchial wall (7). Thus, these lesions should be surgically removed $(7,9)$. According to Kim et al. (1), adequate surgical removal should be the preferred treatment option for all patients among whom GCTs are amenable to surgical resection. They consider that a surgical resection is associated with a lower incidence of recurrence and long disease-free survival. Of 20 surgically treated patients with long term follow up (range 4 months to 12 years), only one was reported to have had symptomatic recurrence (8). Our patient underwent lobectomy and, forty-two months after surgery, the patient remained disease-free.

In conclusion, pulmonary GCTs are rare lesions. Bronchoscopy and biopsies often provide a definitive diagnosis of these tumors. GCTs generally exhibit benign behavior. The patients have an excellent prognosis with a lower incidence of recurrence and long disease-free survival after surgical resection.

\section{CONFLICTS OF INTEREST}

None declared.

\section{AUTHOR CONTRIBUTIONS}

Concept - G.H.E., S.G., A.E., E.A., O.H., A.Y.; Planning and Design - G.H.E., S.G., A.E., E.A., O.H., A.Y.; Supervision - G.H.E., S.G., A.E., E.A., O.H., A.Y.; Funding A.Y., O.H., G.H.E.; Materials - S.G., A.Y., E.A.; Data Collection and/or Processing - G.H.E., A.Y., A.E., O.H., E.A., S.G.; Analysis and/or Interpretation - G.H.E., A.Y., O.H., E.A., S.G.; Literature Review - S.G., A.Y., G.H.E., O.H., A.E.; Writing - A.Y., G.H.E., O.H., S.G.; Critical Review - A.Y., G.H.E., O.H., S.G.

\section{YAZAR KATKILARI}

Fikir - G.H.E., S.G., A.E., E.A., O.H., A.Y.; Tasarım ve Dizayn - G.H.E., S.G., A.E., E.A., O.H., A.Y.; Denetleme - G.H.E., S.G., A.E., E.A., O.H., A.Y.; Kaynaklar - A.Y., 
O.H., G.H.E.; Malzemeler - S.G., A.Y., E.A.; Veri Toplama ve/veya İşleme - G.H.E., A.Y., A.E., O.H., E.A., S.G.; Analiz ve/veya Yorum - G.H.E., A.Y., O.H., E.A., S.G.; Literatür Taraması - S.G., A.Y., G.H.E., O.H., A.E.; Yazıyı Yazan - A.Y., G.H.E., O.H., S.G.; Eleştirel Inceleme A.Y., G.H.E., O.H., S.G.

\section{REFERENCES}

1. Kim HJ, An S, Kim HR. Primary bronchial granular cell tumor in an adult male. Korean J Thorac Cardiovasc Surg 2014; 47:193-6. [CrossRef]

2. van Felius $C L$, Postmus $P E$, Beaumont $F$, Strankinga $W$, Teengs J, Sutedia TG. The role bronchoscpic therapy in bronchial granular cell myoblastoma: presentation of three cases. Diagn Ther Endosc 1996; 2:223-7.

3. Al-Ghamdi AM, Flint JDA, Muller NL, Stewart KC. Hilar pulmonary granular cell tumor: a case report and review of the literature. Ann Diagn Pathol 2000; 4:245-51. [CrossRef]

4. Husain M, Nguyen GK. Cytopathology of granular-cell tumor of the lung. Diagn Cytopathol 2000; 23:294-5. [CrossRef]
5. Meyer MA, Becker JM, Quinones W. Endobronchial granular cell tumor: a case report. J Radiol Case Rep 2010; 4:29-35. [CrossRef]

6. Cutlan RT, Eltorky M. Pulmonary granular cell tumor coexisting with bronchogenic carcinoma. Ann Diagn Pathol 2001; 5:74-9. [CrossRef]

7. Deavers M, Guinee D, Koss MN, Travis WD. Granular cell tumors of the lung. Clinicopathologic study of 20 cases. Am J Surg Pathol 1995; 19:627-35.

8. Hernandez OG, Haponik EF, Summer WR. Granular cell tumour of the bronchus: bronchoscopic and clinical features. Thorax 1986; 41:927-31. [CrossRef]

9. van der Maten J, Blaauwgeers JL, Sutedja TG, Kwa HB, Postmus PE, Wagenear SS. Granular cell tumors of the tracheobronchial tree. J Thorac Cardiovasc Surg 2003; 126:740-3. [CrossRef]

10. Jiang M, Anderson T, Nwogu C, Tan D. Pulmonary malignant granular cell tumor. World J Surg Oncol 2003; $1: 22$. 